\title{
A review of Holarctic species of the genus Tyndaricbus Howard, 1910 (Hymenoptera: Encyrtidae)
}

\section{Обзор голарктических видов рода Tyndaricbus Howard, 1910 (Hymenoptera: Encyrtidae)}

\author{
V.A. Trjapitzin ${ }^{1}$, S.S. Izhevsky ${ }^{2}$, A.K. Akhatov ${ }^{3}$ \\ В.А. Тряпицын ${ }^{1}$, С.С. Изкевский ${ }^{2}$ А.К. Ахатов ${ }^{3}$
}

\footnotetext{
${ }^{1}$ Do vostrebovania, Post Office 129344 (7 ulitsa Letchika Babushkina), Moscow, Russia.

$21^{\text {st }}$ Rizhsky pereulok, 3, apt. 66, Moscow, 129626 Russia.

3 Agrogorodok, 100, apt. 4, Balashikha, Chernoye, Moscow oblast, 143921 Russia.

До востребования, п/о 129344 (ул. Летчика Бабушкина, д. 7), Москва, Россия.

2 1-й Рижский переулок, д 3, кв. 66, Москва, 129626 Россия.

3 Агрогородок, д. 100, кв.4, Балашиха, Черное, Московская обл., 143921 Россия.
}

KEY WORDS: Hymenoptera, Encyrtidae, Tyndarichus, hyperparasitoids, Lepidoptera, Holarctic.

КЛЮЧЕВЫЕ СЛОВА: Hymenoptera, Encyrtidae, гиперпаразитоиды, Lepidoptera, Голарктика.

ABSTRACT. A key to six known Holarctic species of the genus Tyndarichus Howard, 1910 (Hymenoptera: Encyrtidae), four Palearctic and two Nearctic, and their synopsis are provided. Members of this genus with known hosts are hyperparasitoids of Lepidoptera.

РЕЗЮМЕ. В статье приводятся определительная таблица шести известных голарктических видов рода Tyndarichus Howard, 1910 (Hymenoptera: Encyrtidae), четырёх палеарктических и двух неарктических, и дан также их обзор. Виды этого рода с установленными хозяевами являются гиперпаразитоидами чешуекрылых насекомых (Lepidoptera).

\section{Introduction}

This contribution was prompted by necessity to study hyperparasitoids to avoid introduction of them together with primary parasitoids in programs of classical biological control of insect pests.

The article is dedicated to the memory of famous Russian entomologist Nikolay Vasilievich Kurdyumov (1885-1917), in connection with the centennary of his death. His photography (Fig. 1) has been taken in USA in 1909 [Howard, 1930], it was never published in our country.

Acronyms of the depositories of specimens studies are as follows:

CSF - Department of Entomology, California Academy of Sciences, San Francisco, USA;

HMNHB - Hungarian Natural History Museum, Budapest, Hungary;

UCRC — Entomology Research Museum, University

of California, Riverside, USA;

UHF — Department of Agricultural and Forest Zoolo- gy, University of Helsinki, Finland;

UNAM - National Autonomous University of Mexico, Mexico City;

USNM - Museum of Natural History, Washington, DC, USA;

ZIN - Zoological Institute, Russian Academy of Sciences, St. Petersburg, Russia;

ZMUK - Zoological Museum, University of Kopenhagen, Denmark.

$\mathrm{F}$ - the abbreviation for a funicular segment of female antenna.

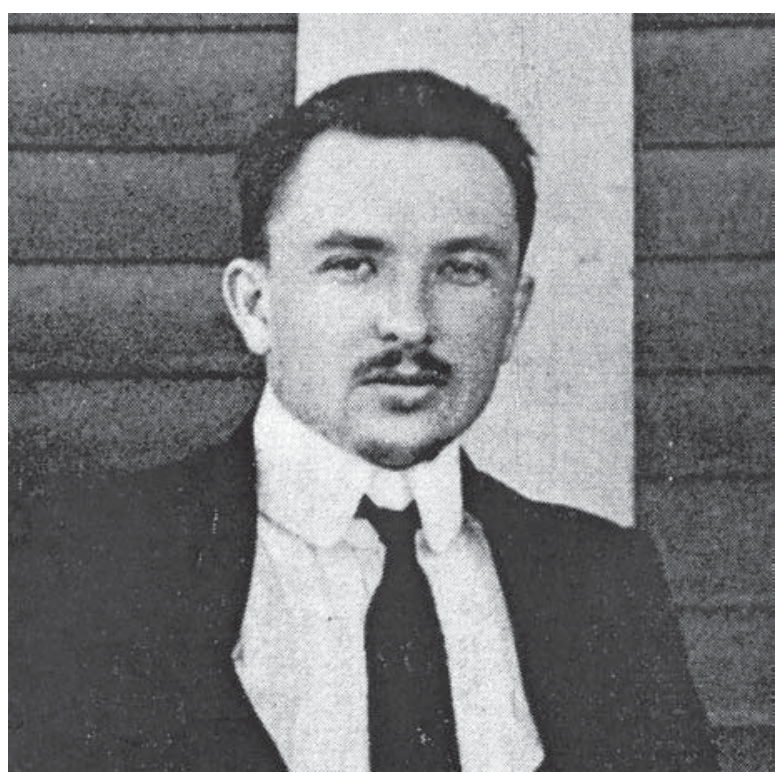

Fig. 1. N.V. Kurdyumov, photography taken in 1909 in USA [from Howard, 1930].

Рис. 1. Н.В. Курдюмов, фотография, снятая в 1909 г. в США [по: Howard, 1930]. 
Genus Tyndarichus Howard, 1910

Type species: Tyndarichus navae Howard, 1910, by original designation.

Howard, 1910: 5-7; Mercet, 1921: 652-654; Gordh, Trjapitzin, 1981: 44-45, 47-48; Kaul, Agarwal, 1985: 39-40; Trjapitzin, 1989: 318-319; Fatima, Shafee, 1993: 72, 74-75; Trjapitzin, Ruíz-Cancino, 2001: 215-217.

SYSTEMATIC POSITION. According to Trjapitzin [1989], the genus Tyndarichus belongs to the subtribe Tyndarichina Erdős et S. Novicky, 1955 of the tribe Cheiloneurini Hoffer, 1955.

NOTES. Tyndarichus kuriri (Fahringer, 1944) has been described from Croatia [In: Kurir, 1944: 581]. It parasitized Anastatus disparis (Ruschka, 1920)* (Hymenoptera: Eupelmidae) in eggs of the gypsy moth Lymantria dispar Linnaeus, 1758. Trjapitzin [1989: 209] supposed that the species might belong to the genus Oobius Trjapitzin, 1963, however it may be uncertain. Bouček [1977] reported that the type materials of this species were not found in Zagreb where believed to be deposited. Thus, generic position of T. kuriri Fahringer, 1944 remains not cleared up.

Outside the Holarctic, three species of Tyndarichus were described from India, viz: T. keralensis (Hayat, 2003), T. nitidulus Hayat, 2003 and T. xesus Hayat et Khan, 2014. One species - T. particornis (Girault, 1924) - was described from Australia. Their biology is unknown.

\section{Key to Holarctic SPECIES OF TYNDARICHUS (FEMALES)}

1(6). F1, or F5-F6, or only F6 more or less light.

2(3). Only F6 light. Width of the vertex about $1 / 4$ of maximum width of head. Apex of scutellum smooth. [Funicular segments of antenna very short (Fig. 3)]. 1.2-1.8 mm

4. T. navae

3(2). F5-F6 light. Width of vertex about $1 /{ }_{3}$ of maximum width of head. Apex of scutellum sculptured.

4(5). Scape of antenna (Fig. 4) strongly broadened, 2-2.2 $\mathrm{x}$ as long as wide; pedicel as long as F1-F5 taken together. 1$1.4 \mathrm{~mm}$ 2. T. ibarrai

5(4). Scape of antenna (Fig. 6) not strongly broadened, more than $3 \mathrm{x}$ as long as wide; pedicel as long as F1-F3 taken together. $1.5-1.8 \mathrm{~mm}$ 3. T. melanacis

6(1). All funicular segments of antenna dark.

7(8). Scape of antenna (Fig. 7) strongly broadened. 1.1-1.7 $\mathrm{mm}$

6. T. scaurus

8(7). Scape of antenna not broadened.

9(10). F5-F6 transverse (Fig. 8); antennal clava 2x as long as wide. [Body length not indicated in description] ...........

............. T. americanus

10(9). F5-F6 quadrate; antennal clava $4 \mathrm{x}$ as long as wide. $1.08 \mathrm{~mm}$ 5. T. paralourgos

\section{Synopsis of species}

1. Tyndarichus americanus Gordh et Trjapitzin, 1981 Fig. 8.

Gordh, Trjapitzin, 1981: 45-47, 48; Zuparko, 2015: 53-54. MATERIALS EXAMINED. USA: Wisconsin, Door Co. 31.VIII.1931 (M.H. Dooner), 3 +P (holotype and paratypes) [USNM] Utah, Uintah Co., on white sweet clover Melilotus albus (Fabaceae), 11.VII.1974 (G.E. Bohart), 1 ㅇ (paratype) [G.E. Bohart collection] California, Los Angeles Co., Angeles Crest, Highway, Arroyo Seco, Switzer Station, 1000 m, VII.1977 (Paul H. Arnaud, Jr.) 1 क [CSF].

* Anastatus disparis (Ruschka, 1921) is a synonym of A. japonicus Ashmead, 1904
DISTRIBUTION. USA (Wisconsin, Utah, California).

BIOLOGY. According to Zuparko [2015], in California hyperparasitoid of Agrotis ypsilon (Hufnagel, 1766) (Noctuidae) via polyembryonic encyrtid Copidosoma celenae Howard, 1885.

\section{Tyndarichus ibarrai Trjapitzin et Ruíz, 2001} Figs 4-5.

Trjapitzin, Ruíz-Cancino, 2001: 217-218.

MATERIALS EXAMINED: Mexico: Tamaulipas, Miquihuana, bosque pino-encino, 28.IV.1996 (J.S. Ibarra), 1 o (holotype) [UNAM]; Michoacán, 16 mi W Jacona, 1 † (paratype), [UCRC].

DISTRIBUTION. Mexico.

BIOLOGY. Unknown.

\section{Tyndarichus melanacis (Dalman, 1820)} Figs 2, 6 .

[Encyrtus melanacis, Microterys melanacis; syn.: E. jancirus Walker, 1837, synonymy by Bouček, Graham, 1978: 94; T. ignotus Mercet, 1947, only , , synonymy by Noyes, 1981: 185].

Dalman, 1820: 345 (Encyrtus); Walker, 1837: 46-47 (E. jancirus); Mayr, 1876: 703, 717 (Encyrtus); Thomson, 1876: 167-168 (Microterys); Mercet, 1921: 654-655, 1947:462 (T. ignotus); Nikol'skaya, 1952: 462; Erdős, 1957: 373; Nikol'skaya, 1963: 475; Erdős, 1964: 307-308; Trjapitzin, 1978: 312; Noyes, 1981: 185; Herthevtzian, 1986: 87; Trjapitzin, 1989: 319.

MATERIALS EXAMINED: Spain: San Rafael. VII.1922 (C. Bolívar), 1 (det. Mercet) [USNM]. Denmark: E-Jutland, Mols, Skovbjerg, $56^{\circ} 13^{\prime} \mathrm{N}, 10^{\circ} 33^{\prime} \mathrm{E}$ (Munk) [ZMUK]. Finland, $1+$ [UHF]. Germany: Handelsberg b. Fürstenwalde, 18.VIII.1927 (M. Ude S.), 2 우 [HMNHB]; München - Nymphlg - Brunnenhal, 14.VI.1961 (F. Bachmaier), 1 (det. Bachmaier) [ZIN]. Austria: Piesting (Tschek), 1 ( (det. Mayr) [USNM]. Russia [ZIN, mainly collected by V.A. Trjapitzin, other collectors and depositories are mentioned, also in materials from the former USSR, labels in Russian]: Leningrad oblast': Repino, sands, 29.V.1976, 1 ㅇ; Pskov oblast': Pushkinskiye Gory, forest, 25.VIII.1971, 2 + 9 ; Yaroslavl oblast': Breytovo district, Petrovskoe - Musino, forest, 31.VII.1966 (E.Ya. Shuvakhina), 1 O; Kostroma oblast': Manturovo district, Ugory, mixed forest, 21.VIII.1984, 1 ; Davydovo, bank of the river Unzha, on oak Quercus robur, 23.VIII.1984, 1 O.; Shilovo, 24.VIII.1984, 1 ․ Moscow: Pedagogical insectary of Zoological garden, from caterpillar of Sesia apiformis Clemens (Sesiidae), autumn of 1928 (V. Karpov), 2 우; Moscov oblast': Pushkino district, Cherkizovo, bank of the river Klyaz'ma, in grass, 30.VIII.1998 (E.Ya. Shuvakhina), 1 +; Murashki near Cherkizovo, bank of the river Klyaz'ma, collected on birch (Betula), hawthorn (Crataegus) and willow (Salix), 27.VIII.1998, 1 o; railway station Klyaz'ma, 3.IX.1994, 2 o+; Mamontovka [now a district of town Pushkino], a hill near railway station, 23.VIII.1971, 1 ㅇ 5.IX.1976 (E.Ya. Shuvakhina), 2 oo, 11.IX.1981, 3 우; 2.IX.1986, 2 o+ ; forest beyond cementery, 28.VIII.1988, 1 O; on linden Tilia cordata, 6.IX.1994, 6 Oo. ; settlement Sosnovka, near brook Vetelka, 11, 13.IX.2003, 10 우; 12.IX.2007, 2 o+o; Kaluga oblast': Spas-Zagorye, on trees and shrubs, 6.IX.1978, 2 oo; Shemyakino, 5, 6.IX.1978, 3 우; 7.VIII.1979, 1 ; 25, 26.VII.1981, 3 o+ ; Verkhnyaya Vyrka, 2.VIII.1979, 1 o; Nizhnyaya Vyrka, 1.VIII.1979, 1 o; Sivkovo, 16.VIII.1977, 5 OO; 18, 21.VIII.1978, 15 오, 1 ○'; 27.VII.1979, 1 우 9, 11, 12, 18, 28.VIII.1979, 18 우; Golotskoye, 15.VIII.1979, 2 94; Gorenskoye, 2.VIII.1979, 1 9; Optina Pustyn', 16.VIII.1979, 1 영 Nizhny Novgorod oblast': Dzerzhinsk, 22.VIII.1983, 2 ㅇ; Arzamas district, Staraya Pustyn', 24.VIII.1983, 11 o+; Kirov oblast': Falenki, from caterpillar of Agrotis sp. (Noctuidae) on winter rye Secale cereale, 19.VII.1976 (M.S. Malysheva), 3 oO, $1 \sigma^{7}$; the same, on caterpillar of sixth instar of $A$. segetum Denis et Schiffermüller, 1 ? (the parasitoid pierced the caterpillar with ovipositor and licked of its haemolymph); Lipetsk oblast': [natural reserve] Galichya Gora, on birch Betula pendula, 29.VIII.1978, 7 90; Voronezh oblast': Ertil' district, village Jatsheyka, 24.VIII.1980 (V.N. Fursov), 1 웅 Ramon' district, Starozhivotinnoye, 13.VIII.1980, 3 oo; Ramon', VNIIZR, 4.VIII.1980, 1 9, 7.VII.1981, 1 ; Aydarovo near Ramon', 


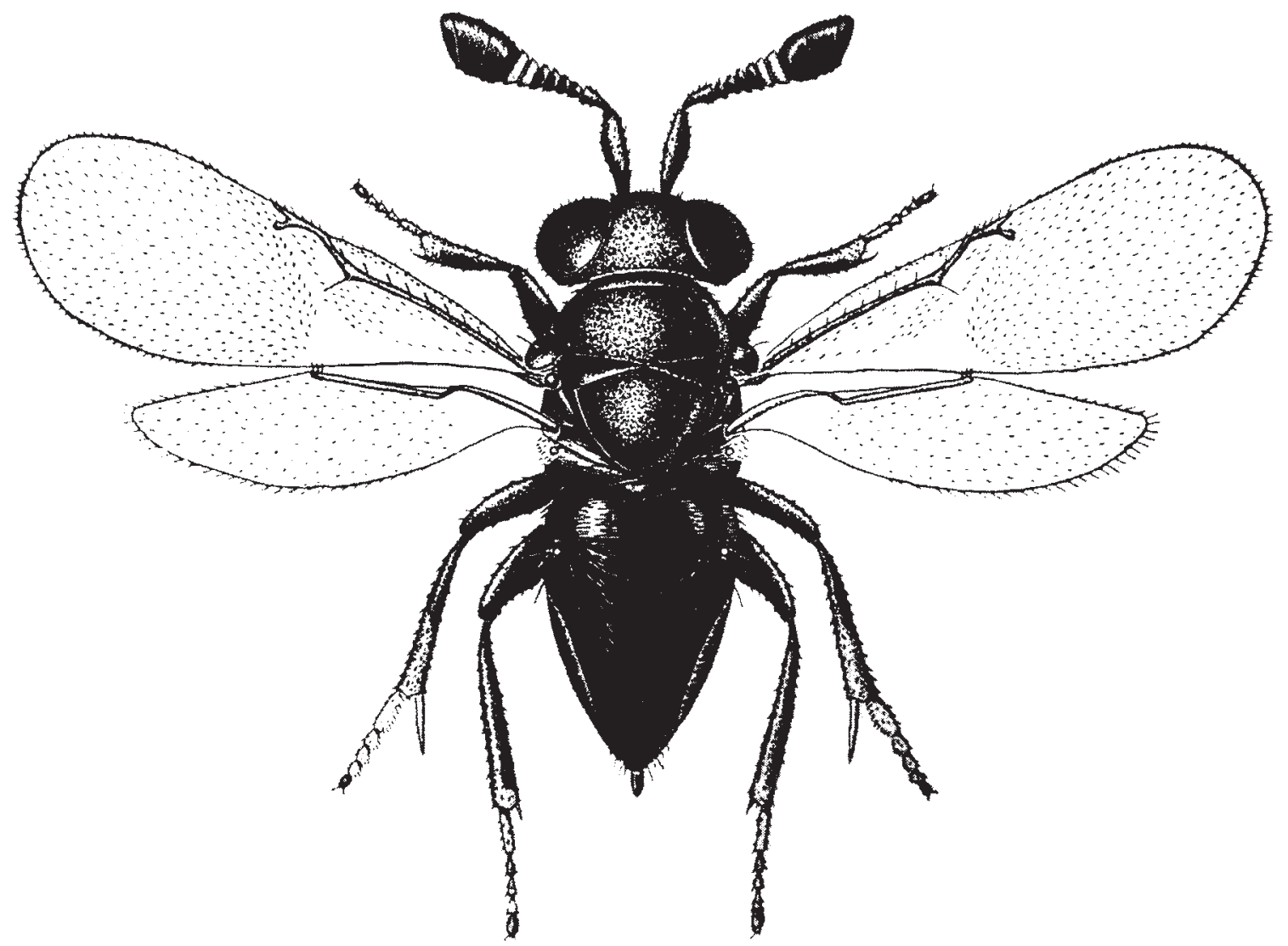

Fig. 2. Tyndarichus melanacis, female habitus [from Erdös, 1964]. Pис. 2. Tyndarichus melanacis, габитус самки [по: Erdös, 1964].

17.VII.1974, 1 연 Ulyanovsk oblast': Ulyanovsk, Zavolzhye, forest, on oak Quercus robur, 13.VIII.1994, 1 +; Shilovka S of Ulyanovsk, game reserve, 14.VIII,1994; Crimea: Mezhgorye, oak-hornbeam forest, 15.IX.1980 (D.R. Kasparyan), 3 oO; Stavropol kray: Essentuki (Belyi Ugol'), slopes of hills, 21.VII.1960 (E.S. Sugonjaev), 1 ; Karachaevo-Cherkesia: Arkhyz, subalpine zone, 2000-2200 m, 1.VIII.1960 (E.S. Sugonjaev), 2 oo; Daghestan, $15 \mathrm{~km} \mathrm{~S}$ of Sergokala, 14-16.VII.1983 (I.M. Kerzhner), 1 †; Altay kray: Lebyazhye (near town Rubtsovsk), Zone forest experiment station, 6.VIII.1948 (M.N. Nikol'skaya), 2 우 and many $\circ$ +⿱ in alcohol Moldavia: Tyrnovo, on apple-tree Malus domestica, 2.VII.1958 (V.I. Talitzky), 1 O; Strasheny, forest, 19.V.1962 (V.I. Talitzky), 1 +. Georgia: Bakuriani, 15.VI.1958, 1 ㅇ 13.IX.1982 (D.R. Kasparyan), 1 ; [without indication of locality], from caterpillars of Zeuzera pyrina (Linnaeus) (Cossidae), series of $\$ \circ$. Armenia: Dilizhan, 17.VIII.1979 (Vásárhely), 1 + [HMNHB]; Tsakhkadzor, oak forest, on Quercus, 22-23.VIII.1956, 1 +. Azerbaijan: Pirkuli, $22 \mathrm{~km}$ of Shemakha, forest, 2.V.1972 (D.R. Kasparyan), 1 ๆ. Kazakhstan: mountains Tastau in western Tarbagatay, $30 \mathrm{~km}$ NE of Blagodarny, 13.VII.1978 (E.P. Nartshuk), 1 9. Kyrghyzstan: Dzhalalabad, KaraKysmak ravine, $42^{\circ} 06^{\prime} \mathrm{N}, 71^{\circ} 33^{\prime} 28^{\prime \prime} \mathrm{E}, 2500$ m, 18.VI.1999, vacuum 99.56.01. (C.H. Dietrich), 1 क [UCRC].

DISTRIBUTION. Spain, Italy, England, Denmark, Norway, Sweden, Finland, Germany, Austria, Czech Republic, Slovakia, Hungary, Montenegro, Romania, Bulgaria, Russia, Estonia, Lithuania, Poland, Moldavia, Ukraine, Georgia, Armenia, Azerbaijan, Kazakhstan, Kyrghyzstan.

BIOLOGY. Data on hosts of $T$. melanacis are scant. Its species had been reared from caterpillars of some Lepidoptera: in Moscow — Sesia apiformis (Clerck, 1755) (Sesiidae), in Kirov oblast' _ Agrotis segetum (Denis et Scliffermüller,
1775) (Noctuidae), and in Georgia - Zeuzera pyrina (Linnaeus, 1761) (Cossidae). Without any doubt, the species is hyperparasitiod via polyembrionic encyrtids of the genus Copidosoma Ratzeburg, 1841. Data on rearing of T. melanacis in Mozambique as hyperparasitoid of coccids (Homoptera: Coccoidea) on citrus cultures [Castel-Branco, 1950] are erroneous. It was a mistake of identification.

NOTE. According to the classification of Gorodkov [1984], T. melanacis is a species with boreal montane distribution.

\section{Tyndarichus navae Howard, 1910}

Fig. 3.

Howard, 1910: 5; Howard, Fiske, 1911: 153, 171, 182-183; Nikol'skaya, 1952: 452; 1963: 475; Tachikawa, 1963: 158-159; Liao, 1978: 95-96; Liao et al., 1987: 181; Trjapitzin, 1989: 318319; Trjapitzin, Paik, 1996: 98-99.

DISTRIBUTION. Japan, North Korea, South Korea, China, Indonesia, Germany, Sweden.

BIOLOGY. In Japan and South Korea, T. navae is an internal hyperparasitoid in eggs of the gypsy moth $L$. dispar, and also L. fumida (Butler, 1877) (Lymantriidae). In China it was reared from eggs of L. dissoluta Swinhoe, 1903. Together with the primary egg parasitoid Ooencyrtus kuvanae (Howard, 1910), T. navae had been introduced into USA against L. dispar (Howard, Fiske, 1911). However it, probably, did not acclimatize there, otherwise it must be mentioned in the review of Noyes et al. [1997]. Surprisingly, Hedqvist [2003] noted presence of T. navae in Sweden, and Hayat [2012] in Germany. 
5. Tyndarichus paralourgos

(Springate et Noyes, 1990)

Springate, Noyes, 1990: 222-224 (Parechthrodryinus); Hayat, 2012: 174.

DISTRIBUTION. England.

BIOLOGY. Unknown.

6. Tyndarichus scaurus (Walker, 1837)

Fig. 7.

[Encyrtus scaurus; syn.: E. genetyllis Walker, 1848, synonymy by Bouček, Graham, 1978: 94].

Walker, 1837: 45-46 (Encyrtus); 1848: 223 (E. genetyllis);
Mayr, 1876: 716, 717 (Encyrtus); Nikol'skaya, 1952: 462; Eady, 1960: 669; Nikol'skaya, 1963: 475; Erdős, 1964: 307, 308; Stadnitzky et al., 1978: 139-140; Trjapitzin, 1978: 312; 1989: 319.

MATERIALS EXAMINED: England: Suffolk, Dunwich, ex larva [of] Eupithecia castigata Hübner (Geometridae), 2.V.1929 (K.G. Blair), 1 [ [det. J. Waterrston] [USNM]; Surrey, Box Hill (near Dorking), herbaceous vegetation, 28.VII.1982 (E.E. Grissell), 1 ㅇ [USNM]; Globham Common, sweeping oak [Quercus], 26.VIII.1982 (E.E. Grissell), $1+$ [USNM]; Richmond Park, on $Q$. robur, 21.VII.1975, 1 \& [det. J.S. Noyes]. Denmark: E. Jutland, NG 36, Viulf Skov, 29.VIII.1984 (T. Munk), 1 [ZMUK]. Finland: 19 [UNF]. Poland: (leg. W.J. Puławski): Wrocław, 24.VI, 17.IX.1961, 2 우, 1 ○$^{\top}$; Pracze, 15 km NW Wrocław, 27.VIII.1961, 2 우 [ZIN].
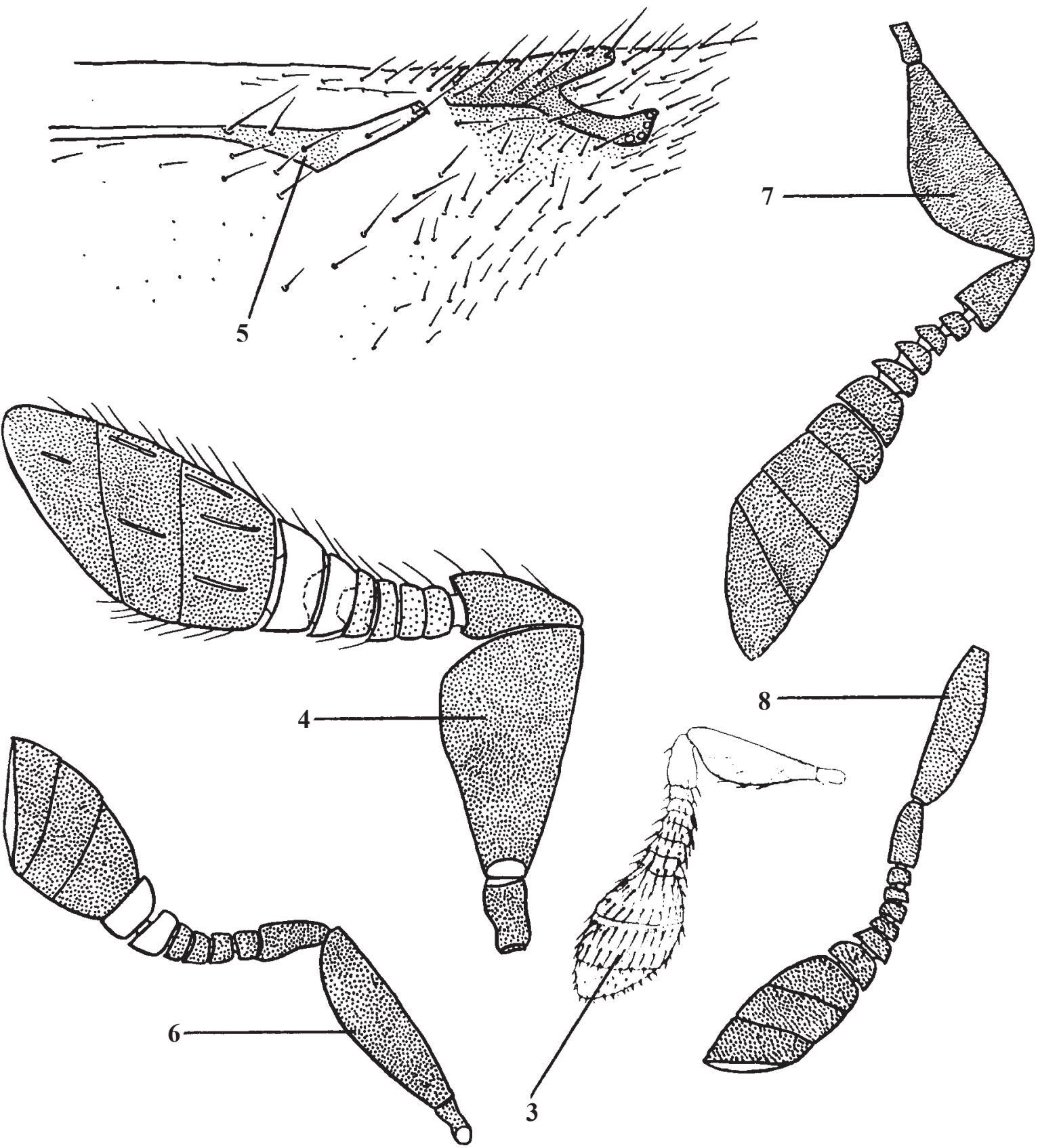
Austria: Piesting [river] (Tschek), "scaurus" [det. G. Mayr], also the label: Encyrtus scaurus, homotype [det. Gahan] [USNM]. Russia [in ZIN, collected by V.A. Trjapitzin, other collectors and depositories are mentioned, also in materials from the former USSR]: Kaliningrad oblast': Yantarny, on sea-buckthorn Hippophae rhamnoides, 27.VIII.1992, 1 q; Leningrad oblast': vicinities of Vyborg, 27.V.1982, 1 ; ; Roshchino, ship grove, bank of the river Lindulovka, 26.IX.1971, 1 \%; Komarovo, 4.VIII.1984, 1 ; ; railway station Kurort near Sestroreck, 15.VIII.1986, 3 of ; Olgino, border of forest, 19.IX.1971, 1 \%; Kolyasovo near Vartemyaki, 9.VIII.1986, 1 웅 Mozhayskaya, 18.IX.1980, 1 +; Sablino, end of VI, 1 +; Novgorod oblast': Stegnovo, from caterpillar of Eupithecia abietaria Goeze, the host was collected 25.VIII, parasitoids issued in laboratory 15.IX.1967 (G.V. Stadnitsky), 1 +, $10^{7}$; Kostroma oblast' (Manturovo district): Ugory, mixed forest, 21.VIII.1984, 2 우; Davydovo, on oak [Quercus robur], 23.VIII.1984, 1 \%; Moscow, park of Timiryazev Agricultural Academy, 27.VII.1960, 1 ; ; Moscow oblast': Zagorsk [now: Sergiev Posad] district, Mitropolye, forest (Piceetum herbosum), 20.VIII.1970, 2 우; Pushkino district: Levkova Gora Zeleny Gorodok, 25.VII.1979, 1 ; Cherkizovo, park near church, on linden Tilia cordata, 27.VIII.1988, 1 \%; Mamontovka [now a district of town Pushkino], a hill near railway station, 23.VIII.1971, 1 ; the same place, 21.VIII.1980, 1 ; settlement Sosnovka, near brook Vetelka, 9.IX.2006. 2 우; Pavlovo-Posad district, Electrogorsk, field, in grass, 21.VIII.1998 (E.Ya. Shuvakhina), 1 +; Kaluga oblast: Shemyakino, 21.VIII.1981, 1 \%; Dvortsy, $25 \mathrm{~km} \mathrm{~W}$ of Kaluga, 30.VII.1980, 1 ; Navoloki, $25 \mathrm{~km}$ O of Kaluga, 29.VII.1980, 3 우; Sivkovo, 27, 31.VII.1980, 4 우; Penza oblast': Virga, mixed forest, 6.IX.1977 (E.N. Khlopunov), 1 \%; Ulianovsk oblast': Ulianovsk, Zavolzhye, bank of water reservoir, 11, 13.VIII.1994, 4 우우 Crimea, forest near Angarsky pass, 10.IX.1971 (D.R. Kasparyan), +; Karachaevo-Cherkesia, Teberda, 20.VIII.1936 (M.N Nikol'skaya), 1 ; ; Novosibirsk oblast': right bank of the river Eltsovka, VII.1965 (Yu. Korshunov), 10 우; Irkutsk oblast': Padun on the river Verkhnyaya Tunguska [now: Angara], N 39 985, 1867 (Czekanowski), 1 ; Balagansk, from caterpillar of Semiothisa coninuaria (Eversman) (Geometridae), 19.VI.1974 (A. Pleshanov), 8 우 ; Buryatia: Naushki by Kyakhta, pine forest, 24.VIII.1962 (K.B Gorodkov), 1 ; Chita oblast': Olovyaninskoye, water-meadow of the river Onon, 9.VII.1971 (D.R. Kasparyan), 1 \%; Primorsky kray: Slavyansk district, apiary (12 km from the settlement (O.V. Kovalev), 1 ; 40 km O of Chuguyevka, 25.VIII.1978 (D.R. Kasparyan), 1 ; Khorol district: Petrovka, slope of hill with bushes and motley grass, 1.VIII.1961 (M.A. Kozlov), 1 +; Suputinsky Natural Reserve, black fir-tree forest with hornbeam, 1.VIII.1961, 1 ; ; bay Tachingon, oak forest, 18.VIII.1961 (M.A. Kozlov), 1 q; Laso district: Kievka, 24.VIII.1961, 1 ; Suchan [now: Partizansk] district, Peretino, 23.VII.1961, 1 +; Kangauz, from a caterpillar of Lepidoptera 29.VII.1972 (V.S. Kuslitsky), 3 우; Vladivostok, Academic campus, 27.VI.1961 (E.Ya. Shuvakhina), 1 웅 Khasan district: source Narva, 4.VIII.1978 (D.R. Kasparyan), 1 +; near the lake Khasan, on oak Quercus dentata, 12.IX.1961 (O.V. Kovalev), 1 ; Kamchatka oblast': Malokurilskoye on the island Shikotan (Kurils), 21.VIII.1971 (D.R. Kasparyan). Estonia: Kuura, 20 km S of Võro, 11.VI.1989, 1 . Belorussia: Minsk district: from caterpillars of Tortricidae, 1968 (A. Moiseenko), 1 +, $1 \mathrm{O}^{\top}$. Moldavia and Dnestr Moldavian Republic [Pridnestrovskaya Moldavskaya Respublika]: Bendery, forest, 1967 (V.I. Talitzky), 1 ㅇ. Armenia: Tsakhkadzor, oak forest, 23.VII.1956, 1 ㅇ.

NOTE. In Primorsky kray of Russia, one female of Tyndarichus scaurus has been catched on light of quartz lamp [Sharkov, 1985].

DISTRIBUTION. Ireland, England, France, Netherlands, Denmark, Norway, Sweden, Finland, Germany, Austria, Czech Republic, Slovakia, Hungary, Italy, Romania, Russia, Estonia, Lithuania, Poland, Belorussia, Moldavia, Dnestr Moldavian Republic, Georgia, Armenia, Mongolia, China.

BIOLOGY. Tyndarichus scaurus had been reared usually from caterpillars of Geometridae, mainly belonging to the genus Eupithecia Curtis, 1825. In Irkutsk oblast' of Russia it issued from Semiothisa coninuaria (Eversman, 1852), and in Sweden - Cidaria ocellata (Linnaeus, 1758). However, in
Norway it was noted as reared from Ypsolopha asperella (Linnaeus, 1761) (Ypsolophidae) on apple-tree Malus domestica. There are only two publications on hyperparasitoitism of T. scaurus: 1) in Russia (Leningrad oblast' and Karelia) it develops as endoparasitoid of polyembryonic encyrtid Copidosoma sp. in caterpillars of Eupithecia abietaria (Goeze, 1781) on spruce Picea abies [Grebenshchikova, 1973; Stadnisky et al., 1978]. These authors expressed an opinion that development of T. scaurus is also polyembryonic, but this question remains unsettled without embryological studies. 2) In Netherlands it is parasitoid of Copidosoma sosares (Walker) in caterpillars of the parsnip moth Depressaria pastinacella (Duponchel, 1837)* (Oecophoridae) on leafs of Pastinaca sativa (Apiaceae) [Hardy, 1996].

NOTE. According to classification of Gorodkov [1984], T. scaurus is a species with boreal montane distribution.

ACKNOWLEDGEMENTS. The authors are thankful to Dr. Serguei Vladimirovich Triapitsyn (University of California, Riverside, CA, USA) for sending some literature necessary for this article.

\section{References}

Bouček Z. 1977. A faunistic review of the Yugoslavian Chalcidoidea (parasitic Hymenoptera) // Acta Entomologica Jugoslavica (Zagreb). Vol. 13 (Suppl.). P.1-145.

Bouček Z., Graham M.W.R. de V. 1978. Chalcidoidea // A check list of British Insects. Handbook for the Identification of British Insects. Vol.11. Pt.4. Hymenoptera. P. 67-110.

Castel-Branco A.J.F. 1950. Hiperparasita de cochonilhas das citrinas (Tyndarichus melanacis Dalman) em Moçambique // Junta das Missioes Georgráficas e Investigação Colonias, Lisboa. Anais. Vol.V. T.VI. Fasc.1. Trabajos da Missão Zoológica de Moçambique. Ser.5. P.91-102.

Dalman J.A. [W.]. 1820. Försök till upställning af insect-familjen Pteromalini, i synnerhet med afsunde på de i Sverige funne arter // Kunigliga Svenska Vetenskapsakademiens Handlingar. T.41. H.1/2. S.123-174, 177-182, 340-385.

Eady R.D. 1960. A new genus and two new species of Encyrtidae (Hymenoptera, Chalcidoidea) from the banana scab moth, $\mathrm{Na}$ coleia ostasema (Meyr.) // Bulletin of Entomological Research. Vol.50. Pt.4. P.667-670.

Erdős J. 1957. Miscellanea chalcidologica hungarica // Annales Historico-Naturales Musei Nationalis Hungarici (Series nova). T.8. P.347-374.

Erdős J. 1964. 10 család: Encyrtidae - szívarványfürkészek // Fémfürkészek: Magyarország Állatvilága. XII Köt. Hymenoptera II. 4. Füz. Fémfürkészek - Chalcidoidea III. Budapest. 320 oldalok. (Fauna hung.; No.73).

Fatima A., Shafee S.A. 1993. Studies on the taxonomy of the Indian encyrtids (Hymenoptera: Encyrtidae) // Aligarh Muslim University Publication, [Zoological Series] on Indian Insect Types. Vol.15. P.1-141.

Gordh G., Trjapitzin V.A. 1981. Taxonomic studies of the Encyrtidae with descriptions of new species and a new genus (Hymenoptera, Chalcidoidea) // University of California Publications in Entomology. Vol.93. P.i-vi + 1-64.

Gorodkov K.V. 1984. [Ranges types of insects of tundra and forest zones of European Part of USSR] // Gorodkov K.V. (ed.). Atlas arealov nasekomykh Evropeiskoi chasti SSSR. P.3-20 [in Russian].

Grebenshchikova V.P. 1973. [Natural enemies of main pets of seeds and cones of spruce, and means of their use]. Autoreferate of the Thesis of Candidate (Ph.D.) of Biological Sci. Degree. Leningrad Forest-technical Academy. 22 p. [in Russian].

* Depressaria pastinacella (Duponchel, 1837) is a synonim D. radiella (Goeze, 1783) 
Hardy J.C.W. 1996. Precocious larvae of the polyembryonic parasitoid Copidosoma sosares (Hymenoptera: Encyrtidae) // Entomologische Berichte (Amsterdam). D.56. No.5. S.88-92.

Hayat M. 2012. Taxonomic notes on Indian Encyrtidae (Hymenoptera: Chalcidoidea). — VI // Oriental Insects. Vol.46. No.2. P.163181.

Hedqvist K.-J. 2003. Katalog över svenska Chalcidoidea // Entomologisk Tidskift. Vol.124. Nos1-2. P.73-133.

Herthevtzian E.K. 1986. [Encyrtids ( Encyrtidae) of Armenian SSR] Fauna of Armenian SSR: hymenopterous insects. Edition of Academy of Sciences of Armenian SSR, Institute of Zoology. Erevan. 228 p. [in Russian]

Howard L.O. 1910. On some parasites reared or supposed to be reared from the eggs of the gypsy moth // Technical Series, Bureau of Entomology, United States Department of Agriculture. No.19. Pt.1. P.i-iv $+1-12$.

Howard L.O. 1930. A history of applied entomology (somewhat anecdotal) with 51 plates // Smithsonian Miscellaneous Collections. Vol.84. Publication 3065, City of Washington, Smithsonian Institution. The Lord Baltimore Press, Baltimore, Maryland, USA. i-viii + $564 \mathrm{p}$

Howard L.O., Fiske W.F. 1911. The importation into United States of the parasites of the Gypsy Moth and the Brown-tail Moth: a report of progress, with some considerations of previous and concurren efforts of this kind // Bulletin of the Bureau of Entomology, United States Department of Agriculture. No.91. P.1-312.

Kaul K., Agarwal M.M. 1985. Taxonomic studies on encyrtid parasitoids (Hymenoptera: Chalcidoidea) of India (with XVII plates) // Aligarh Muslim University Publications, [Zoological Series] on Indian Insect Types. Vol.13. P.i-viii + 1-89.

Kurir A. 1944. Anastatus disparis Ruschka Eiparasit des Lymantria dispar // Zeitschrift für angewandte Entomologie. Bd.30. H.4. S.551-586.

Liao Ding-shi. 1978. [Natural enemies of insects in China]. Peking [Bejing]. 300 p. [in Chinese].

Liao Dingxi, Li Xueliu, Pang Xiongfei, Chen Tailu. 1987. [Hymenoptera: Chalcidoidea (1)] // Economic Insect Fauna of China. Fasc.34. P.1 -241 [in Chinese]

Mayr G. 1876. Die europäischen Encyrtiden // Verhandbungen der Zoollogisch-Botanischen Gesellschaft in Wien. Bd.25. S.675-778

Mercet R.G. 1921. Himenópteros fam. encírtidos. Fauna Ibérica. Madrid. XI + $732 \mathrm{p}$

Mercet R.G. 1947. Cuatro especies e un género nuevo de calcídidos // Revista de la Real Academia de Ciencias de Madrid. T.41. P.461-468.

Nikol'sksya M.N. 1952. [Chalcids of the fauna of the USSR (Chal- cidoidea)]. Nauka Publishing, Leningrad Branch. Moscow Leningrad. 574 p. [in Russian].

Nikol'skaya M.N. 1963. The chalcid fauna of the USSR (Chalcidoidea). Israel Program of Scientific Translations. Jerusalem. $593 \mathrm{p}$.

Noyes J.S. 1981 (1979/1980). On the types of the species of Encyrtidae described by R. García Mercet (Hymenoptera, Chalcidoidea) // Eos. T.55/56. P.165-189.

Noyes J.S., Woolley J.B., Zolnerowich G. 1997. Chapter 8. Encyrtidae // Gibson G.A.P., Huber J.T., Woolley J.B. (eds.). Annotated keys to the genera of Nearctic Chalcidoidea (Hymenoptera). Ottawa: NRC Research Press. P.170-320.

Sharkov A.V. 1985. [New and little known species of encyrtids (Hymenoptera, Encyrtidae) collected in light traps in the Primorsky Territory] // Trudy Zoologicheskogo instituta AN SSSR. Vol.132. P.20-30 [in Rusian].

Springate N.D., Noyes J.S. 1990. A review of British species of Anagyrus Howard (Hymenoptera: Encyrtidae) with new records and descriptions of other Chalcidoidea // Entomologist's Gazette. Vol.41. P.213-230.

Stadnitzky G.V., Yurchenko G.I., Smetanin A.N., Grebenshchikova V.P., Pribylova M.V. 1978. [Pest of cones and seeds of coniferous plants]. Moscow: Lesnaya Promyshlennost'. 168 p. [in Russian]

Tachikawa T. 1963. Revisional studies of the Encyrtidae of Japan (Hymenoptera: Chalcidoidea) // Memoris of the Ehime University, Sect. IV (Agriculture). Vol.9. No.1. P.1-264.

Thomson C.G. 1986. Skandinaviens Hymenoptera. Lund. D.4. 259 p.

Trjapitzin V.A. 1978. [Fam. Encyrtidae - encyrtids] // Trjapitzin V.A. (ed.). Opredelitel nasekomykh Europeiskoy chasti SSSR. Vol.3 (Hymenoptera). Pt.2. Leningrad: Nauka Publishing, Leningrad Branch. P.236-328 [in Russian].

Trjapitzin V.A. 1989. [Parasitic Hymenoptera of the fam. Encyrtidae of Palearctic]. Leningrad, Nauka Publishing, Leningrad Branch. 489 p. [in Russian].

Trjapitzin V.A., Paik J.C. 1996. Notes on some Encyrtidae (Hymenoptera, Chalcidoidea) from Korean Peniusula // Korean Journal of Applied Entomology. Vol.35. No.2. P.95-100.

Trjapitzin V.A., Ruíz-Cancino. 2001. Especie nueva de Tyndarichus (Hymenoptera: Chalcidoidea: Encyrtidae) de Tamaulipas y Michoacán, México // Anales del Instituto de Biología, Universidad Autónoma de México, Série Zoología. Vol.72. No.2. P.215-220. Walker F. 1837. Monographia Chalciditum. Vol.5. P.35-55.

Walker F. 1848. List of specimens of hymenopterous insects in the collection of the British Museum. Pt.2: Chalcidites. London. IV $+237 p$.

Zuparko R.L. 2015. Annotated checklist of California Encyrtidae (Hymenoptera) // Zootaxa. Vol.4017. No.1. P.1-126. 